\title{
Pengaruh Rasio Aktivitas, Produktivitas dan Profitabilitas terhadap Likuiditas pada Perusahaan Manufaktur di Bursa Efek Indonesia
}

\author{
Putri Yanti ${ }^{1}$, Neni Marlina Purba ${ }^{2}$ \\ ${ }^{1}$ Akuntansi, Ilmu Sosial dan Humaniora, Universitas Putera Batam \\ ${ }^{2}$ Akuntansi, Ilmu Sosial dan Humaniora, Universitas Putera Batam \\ ${ }^{I}$ pb160810085@upbatam.ac.id
}

\begin{abstract}
The purpose of this study was to determine the effect of the Activity, Productivity and Profitability ratios on liquidity in Indonesian stock exchange companies. The independent variables used in this study are the ratio of activities, productivity ratios, and profitability ratios. Meanwhile, what is used as the dependent variable is the liquidity used based on the Indonesian Stock Exchange (IDX) company. The population used in this study were all manufacturing companies in the food and beverage sub-sector, totaling 17 companies. The data used is from companies that publish complete financial statement data for the 2015-2019 period. Based on the calculation results obtained t-count $-2.131<-2.03951$ and the significance level is $0.041<0.05$, it is concluded that $H 1$ is accepted, which means that there is a significant negative effect between the ratio of activity to liquidity. The productivity ratio is -0.508> -2.03951 while the significance level is 0.615>0.05. So that the hypothesis H2 is rejected, which means that there is no influence between the productivity ratio to liquidity. Profitability ratio obtained t-value of 7.933> 2.03951 and a significance value of $0.000<0.05$, so that the hypothesis $\mathrm{H3}$ is accepted, which means that there is a positive and significant effect on the ratio of profitability to the liquidity ratio and the results of data analysis obtained an $f$-count value of 24.014>2.90 and a significance value. 0.000 $<0.05$. This shows that the activity, productivity and profitability ratios simultaneously have a significant effect on the liquidity ratio.
\end{abstract}

Keywords: Activity ratios, productivity, profitability

\begin{abstract}
Abstrak
Tujuan dari penelitian ini adalah untuk mengetahui pengaruh Rasio Aktivitas, Produktivitas, dan Profitabilitas terhadap likuiditas pada perusahaan bursa efek Indonesia. Variabel independen yang digunakan pada penelitian ini adalah rasio dari aktivitas, rasio produktivitas, dan rasio profitabilitas. Sedangkan yang dijadikan sebagai variabel dependent adalah likuiditas digunakan dengan berdasarkan perusahaan Bursa Efek Indonesia (BEI). Populasi yang digunakan dalam penelitian ini adalah semua perusahaan manufaktur subsektor makanan dan minuman yang berjumlah 17 perusahaan. Data yang digunakan dari perusahaan yang mempublish data laporan keuangan lengkap untuk periode tahun 2015-2019. Berdasarkan hasil perhitungan diperoleh t-hitung -2,131<2.03951 dan tingkat signifikansinya $0,041<0,05$, disimpulkan bahwa H1 diterima yang berarti terdapat pengaruh negatif signifikan antara rasio aktivitas terhadap likuiditas. Rasio produktivitas sebesar $-0,508>-$ 2.03951 sedangkan tingkat signifikansinya yaitu 0,615 > 0,05. Sehingga hipotesis H2 ditolak yang berarti bahwa tidak terdapat pengaruh antara rasio produktivitas terhadap likuiditas. Rasio profitabilitas diperoleh nilai t-hitung sebesar $7.933>2.03951$ dan nilai signifikansi sebesar $0.000<0.05$, sehingga hipotesis $\mathrm{H} 3$ diterima yang berarti terdapat pengaruh positif dan signifikan rasio profitabilitas terhadap rasio likuiditas dan hasil analisis data diperoleh nilai f-hitung $24,014>2.90$ dan nilai signifikansi $0.000<0,05$. Hal tersebut menunjukkan bahwa rasio aktivitas, produktivitas dan profitabilitas secara simultan berpengaruh signifikan terhadap rasio likuiditas. Kata kunci: Rasio Aktivitas, produktivitas, profitabilitas.
\end{abstract}




\section{Pendahuluan}

Memaksimalkan laba atau keuntungan perusahaan merupakan tujuan utama perusahaan. Laba atau keuntungan perusahaan adalah salah satu bentuk kinerja perusahaan, semakin tinggi laba atau keuntungan sebuah perusahaan maka kinerja perusahaan tersebut akan dianggap semakin baik pula. Selanjutnya ketika laba sudah maksimal tentunya akan berdampak pada kemakmuran pemilik perusahaan atau modal sehingga Terakhir tingkat likuditias perusahaan diduga mengakibatkan peningkatan pada nilai perusahaan dipengaruhi oleh profitabilitas perusahaan tersebut. Sehingga berdasarkan definisi diatas dapat disimpulkan Perusahaan yang baik harus memiliki rasio bahwa tujuan utama perusahaan adalah untuk profitabilitas perusahaan yang positif atau meningkatkan nilai perusahaan. Perusahaan mencerminkan keuntungan. Karena dengan keuntungan dipengaruhi oleh banyak hal antara lain likuiditas perusahaan tersebut dapat melanjutkan kegiatan perusahaan itu sendiri. Para manajer harus berhati-hati operasional perusahaan serta meningkatkan nilai dalam menentukan faktor-faktor yang paling usahanya sehingga akan mempermudah perusahaan berpengaruh dalam meningkatkan likuiditas untuk menarik dana dari pihak luar baik berupa perusahaanAgar dapat menyelesaikan kewajiban jangka pinjaman atau sumber pendanaan lainya. Hal ini pendeknya juga memiliki pengaruh terhadap likuiditas. diperkuat dengan penelitian yang menyatakan Dimana perusahaan dikatakan likuid apabila bahwapertumbuhan penjualan dapat diartikan sebagai perusahaan mampu untuk membayar kewajiban Laba merupakan salah satu unsur yang harus dipenuhi tersebut.

Masalah likuiditas merupakan salah satu masalah Kemajuan usaha secara finansial biasanya diukur penting dalam suatu perusahaan yang relatif sulit dengan melihat kemampuan manajemen perusahaan dipecahkan, dimana manajer harus mampu melakukan dalam mengelola aset maupun modal untuk perencanaan dan pengendalian aktivas lancar dan mendapatkan keuntungan atau profi[2]. Tidak ada hutang lancarnya sedemikian rupa untuk dapat perusahaan yang berorientasi pada profit yang tidak meminimalkan risiko ketidakmampuan perusahaan mengutamakan laba dalam usahanya. Laba merupakan dalam memenuhi pinjaman dalam waktu yang keuntungan yang diperoleh dari selisih pendapatan ditentukan. Aktivitas suatu perusahaan membutuhkan dengan pengeluaran atau beban.Pada penelitian investasi, baik dan investasi tersebut bisa saja memiliki sebelumnya yang dilakukan oleh melalui penelitian usia pemanfaatan dalam jangka waktu yang telah menyatakan bahwa variabel perputaran persediaan ditentukan.

secara parsial tidak berpengaruh signifikan terhadap likuiditas, perputaran piutang secara parsial

Rasio aktivitas digunakan untuk mengukurseberapa efektif perusahaan dalam menggunakan aktivanya. Dua berpengaruh signifikan terhadap likuiditas[1].

diantara beberapa rasio aktivitas adalah perputaran dan perputaran persediaan dan perputaran piutang persediaan dan perputaran aset tetap. Perputaran secara simultan berpengaruh secara signifikan terhadap persediaan dan perputaran aset tetap yang besar Likuiditas. Rasio Likuiditas adalah rasio yang mengindikasikan besarnya pemanfaatan aset menunjukkan kemampuan perusahaan untuk memenuhi perusahaan serta banyaknya produk yang terjual habis kewajiban finansial yang berjangka pendek tepat pada dan digantikan oleh produk yang baru. Hal ini waktunya. Rasio likuiditas meliputi:

menunjukkan perputaran persediaan dan perputaran aset tetap likuiditas perusahaan. menyatakan bahwa rasio aktivitas digunakan untuk mengukur efektivitas perusahaan dalam menggunakan aktiva yang dimilikinya[1]. Selain rasio aktivitas, rasio produkivitas juga merupakan salah satu yang mempengaruhi likuiditas.

Rasio Produktiviti mengukur seberapa berkesan syarikat menggunakan sumber syarikat. Syarikat dengan produktiviti tinggi cenderung dapat menjana keuntungan yang lebih tinggi berbanding syarikat dengan produktiviti rendah. Semakin tinggi nisbah

Current Ratio (CR) Dengan teknik CR ini tujuannya adalah mengetahui sebuah usaha ataupun kemampuan perusahaan dalam menyelesaikan urusan keuangan baimdalam waktu jangka panjang maupun dalam jangka waktu pendek yang akan datang pada waktunya akan dimintai secaara keseluruhan.

Quick Ratio QR adalh sebuah proses keuangan yang proses pelaporannya tanpa ada kendala. quick ratio yang rendah menunjukkan adanya investasi yang sangat besar dalam persediaan atau disebabkan perputaran persediaan yang lambat.

produktiviti semakin baik penilaian syarikat. Sekiranya Cash ratio adalah sebuah kemampuan dalam proses produktiviti tinggi, kemungkinan besar syarikat tersebut menyelesaikan pinjman pada sebuah perusahaan yang diklasifikasikan sebagai gred pelaburan, kerana dengan harus diselesaikn tepat waktu oleh sebuah perusahaan 
yang berhubungan dengan kondisi keadaan uang kas perusahaan untuk penyelesaian pinjaman

Menurut [1], "perbaningan aktivitas yang dilakukan oleh perusahaan dalam mendapatkan hasil keuangan ataupun keuntungan yang maksimal pada sebuah perushaan". Yang termasuk dalam rasio aktivitas adalah:

\section{Inventory Turn Over}

Perbandingan perputaran adaalh untuk mengetahui dpersediaan dari sebuah perusahaan dan mengkur jumlah persediaan yang akan dijual dalam kurun waktu tetenu oleh perusahaanFixed Asset Turn Over merupakan rasio antara penjualan dengan aktiva tetap netto. Rasio ini menunjukkan bagaimana perusahaan menggunakan aktiva tetapnya seperti gedung, kendaraan, mesin- mesin, dan perlengkapan kantor.

Average Collection Period adalah Teori ini digunakan untuk mengmpulkan pnjaman yairu denagn menghitung rata-rata yang dibtuhkan menjadi kas perusahaan. Teknik ini biasanya digunakan denagn membagi hasil penjualan rata-rata setiap harinya.

Receivable Turn Over adalah Teknik ini digunakan untuk menjelaskan tentang quality pinjaman perusahaan dan kelancaran dalam proses mengumpulkan kondisi pijnaman piutang denan cara mengejar perputaran pituang maka dengan kesimpulan CR dan QR nya akan semakin bagus dalam manage keuangan. Working Capital Turn OverDengan kondisi yang telah ditentukan adalah dengan cara smakin cepat perputaran modal kerja maka current ratio dan quick ratio yang dimiliki akan semakin bagus.

Pengertian produktivitas nisbah produktiviti mengukur seberapa berkesan syarikat menggunakan sumbernya. Secara umum, nisbah produktiviti kerja adalah hasil perbandingan atau peratusan antara Output dan Input[1].Rasio profitabilitas Nisbah keuntungan menegetahui kekuatan syarikat untuk menjana untung pada tahap jualan, harta dan modal saham tertentu [2]. Rasio profitabilitas mencontohkan kekuatan perusahaan memperoleh keuntungan dengan cara segala kemampuan dan sumber yang tersedia. [1].

\section{Metode Penelitian}

Riset ini memanfaatkan faedah penyelidikan kuantitatif, penyelidikan kuantitatif bisa mengetahui hubungan pemboleh ubah dengan objek yang dikaji lebih banyak anatara adanya penyebab dan juga ada akibatnya, sehingga dalam penyelidikannya terdapat pemboleh ubah bebas dan bersandar [4]. Untuk dapat melihat lebih jelas arah atau alur penelitian ini maka desainnya adalah:

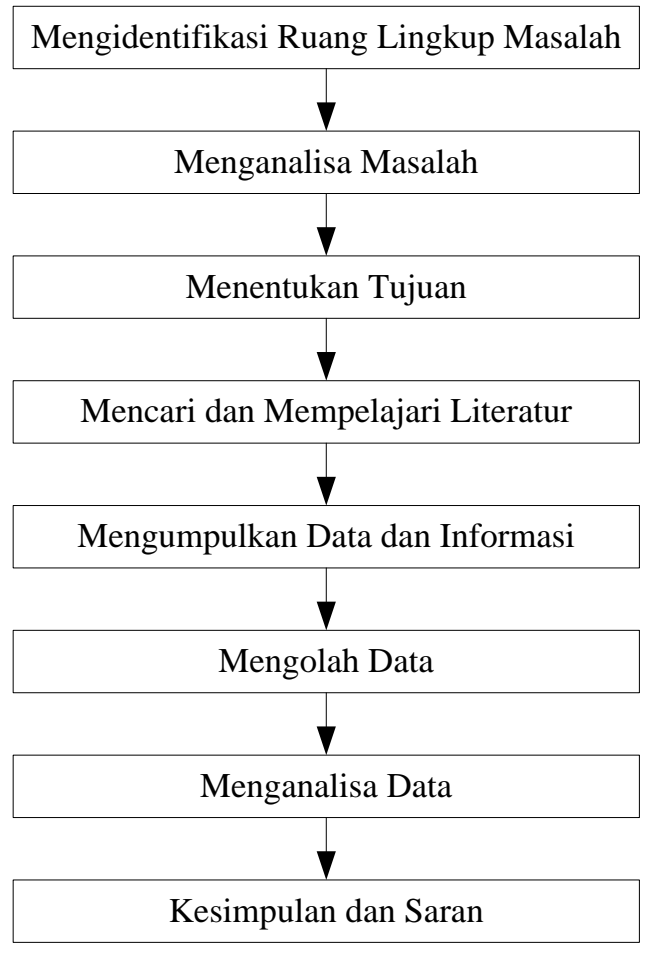

Gambar 1. Desain Penelitian

Variabel Dependen

Variabel dependen dalam penelitian ini adalah rasio likuiditas yang diukur dengan menggunakan Current Rasio. Variabel Independen

Variabel inndependen dalam penelitian ini terdari dari 3 variabel yaitu:

1. Rasio aktivitas yang diukur dengan menggunakan rasio perputaran total asset.

2. Rasio produktivitas yang diukur dengan menggunakan hasil output perusahaan.

3. Rasio profitabilitas yang diukur dengan menggunakan rasio Retun On Asset (ROA). Untuk lebih jelasnya mengenai operasional variabel pada penelitian ini, maka dapat di lihat pada tabel 1 berikut ini: 
Tabel 1 Definisi Operasional Variabel

\begin{tabular}{|c|c|c|}
\hline Variabel & Defenisi & Rumus \\
\hline $\begin{array}{c}\text { Rasio Likuiditas } \\
\text { (Y) }\end{array}$ & $\begin{array}{l}\text { Nisbah ini } \\
\text { dimanfaatkan } \\
\text { adalah dalam } \\
\text { mengkaji } \\
\text { kesanggupan } \\
\text { dalam proses } \\
\text { pelunasan hutang } \\
\text { yang segera } \\
\text { diselasaikan } \\
\text { dengan modal } \\
\text { perusahaan, iaitu } \\
\text { dengan } \\
\text { membandingkan } \\
\text { wang tunai yang } \\
\text { ada di syarikat } \\
\text { dengan hutang } \\
\text { semasa. }\end{array}$ & $=\frac{\text { Aset Lancar }}{\text { Hutang lancar }}$ \\
\hline $\begin{array}{l}\text { Rasio Aktivitas } \\
\left(\mathrm{X}_{1}\right)\end{array}$ & $\begin{array}{lr}\text { Nisbah ini } \\
\text { digunakan untuk } \\
\text { mengukur } \\
\text { kecekapan } \\
\text { pengurusan } \\
\text { inventori dalam } \\
\text { sebuah syarikat } \\
\text { untuk } \\
\text { memperoleh } \\
\text { penjualan }\end{array}$ & $\frac{\text { Penjualan }}{\text { Persediaan }}$ \\
\hline $\begin{array}{l}\text { Produktivitas } \\
\left(\mathrm{X}_{2}\right)\end{array}$ & $\begin{array}{l}\text { nisbah } \\
\text { produktiviti } \\
\text { mengukur } \\
\text { seberapa berkesan } \\
\text { syarikat } \\
\text { menggunakan } \\
\text { sumbernya }\end{array}$ & $=\frac{\text { Penjualan }}{\text { Total Asset }}$ \\
\hline $\begin{array}{l}\text { Profitabilitas } \\
\left(\mathrm{X}_{3}\right)\end{array}$ & $\begin{array}{l}\text { Nisbah ini } \\
\text { dimanfaatkan } \\
\text { sebelum cukai } \\
\text { dari jumlah aset }\end{array}$ & $=\frac{\text { Laba Sebelum Paja }}{\text { Total Aktiva }}$ \\
\hline
\end{tabular}

\section{Populasi}

Untuk melanjutkan penelitian berikutnya dengan mengambil beberapa data yang telah dipilih dengan teknik yang telah ditentukan yaitu manufaktur subsektor makanan dan minuman yang berjumlah 17 perusahaan.

\section{Sampel}

Persampelan dalam kajian ini menggunakan teknik persampelan bertujuan iaitu dengan memilih bahan riset menetapkan kriteria tertentu berdasarkan riset tertentu dengan tujuan kajian [3]. Dari data dan teori yang terlmpir mka diambil sebuah smpel, yaitu:

1. Penelitian ini di lakukan pada perusahaan yang bergerak disektor makanan dan minuman.

2. Perusahaan yang mempublish data laporan keuangan lengkap untuk periode tahun 2015-2019.
3. Perusahaan yang menggunakan laporan keuangan satuan rupiah.

4. Perusahaan yang memenuhi semua data yang dibutuhkan oleh peneliti.

Tabel 2. Tabel Pemilihan Sampel

\begin{tabular}{|c|c|c|c|c|c|c|}
\hline \multirow[t]{2}{*}{ No. } & \multirow[t]{2}{*}{ Nama Perusahaan } & \multirow{2}{*}{$\begin{array}{c}\text { Kode } \\
\text { Perusahaan }\end{array}$} & \multicolumn{4}{|c|}{ Kriteria } \\
\hline & & & 1 & 2 & 3 & 4 \\
\hline 1. & $\begin{array}{l}\text { Campina Ice Cream } \\
\text { Industry Tbk }\end{array}$ & CAMP & $\sqrt{ }$ & - & $\sqrt{ }$ & - \\
\hline 2. & $\begin{array}{l}\text { Tiga Pilar Sejahtera } \\
\text { Food Tbk }\end{array}$ & AISA & $\sqrt{ }$ & $\sqrt{ }$ & $\sqrt{ }$ & - \\
\hline 3. & Tri Banyan Tirta Tbk & ALTO & $\sqrt{ }$ & $\sqrt{ }$ & $\sqrt{ }$ & $\sqrt{ }$ \\
\hline 4. & $\begin{array}{l}\text { Wilmar Cahaya } \\
\text { Indonesia Tbk }\end{array}$ & CEKA & $\sqrt{ }$ & - & $\sqrt{ }$ & - \\
\hline 5. & Sariguna Primatirta Tbk & CLEO & $\sqrt{ }$ & - & $\sqrt{ }$ & $\sqrt{ }$ \\
\hline 6. & Delta Djakarta Tbk & DLTA & $\sqrt{ }$ & $\sqrt{ }$ & $\sqrt{ }$ & $\sqrt{ }$ \\
\hline 7. & $\begin{array}{l}\text { Buyung Poetra } \\
\text { Sembada Tbk }\end{array}$ & HOKI & $\sqrt{ }$ & - & $\sqrt{ }$ & $\sqrt{ }$ \\
\hline 8. & $\begin{array}{l}\text { Indofood CBP Sukses } \\
\text { Makmur Tbk }\end{array}$ & ICBP & $\sqrt{ }$ & $\sqrt{ }$ & $\sqrt{ }$ & $\sqrt{ }$ \\
\hline 9. & $\begin{array}{l}\text { Indofood Sukses } \\
\text { Makmur Tbk }\end{array}$ & INDF & $\sqrt{ }$ & - & $\sqrt{ }$ & $\sqrt{ }$ \\
\hline 10 & $\begin{array}{l}\text { Multi Bintang Indonesia } \\
\text { Tbk }\end{array}$ & MLBI & $\sqrt{ }$ & $\sqrt{ }$ & $\sqrt{ }$ & - \\
\hline 11. & Mayora Indah Tbk & MYOR & $\sqrt{ }$ & $\sqrt{ }$ & $\sqrt{ }$ & $\sqrt{ }$ \\
\hline 12. & $\begin{array}{l}\text { Prasidha Aneka Niaga } \\
\text { Tbk }\end{array}$ & PSDN & $\sqrt{ }$ & - & $\sqrt{ }$ & $\sqrt{ }$ \\
\hline 13. & $\begin{array}{l}\text { Nippon Indosari } \\
\text { Corpindo Tbk }\end{array}$ & ROTI & $\sqrt{ }$ & $\sqrt{ }$ & $\sqrt{ }$ & - \\
\hline 14. & Sekar Bumi Tbk & SKBM & $\sqrt{ }$ & - & $\sqrt{ }$ & - \\
\hline 15. & Sekar Laut Tbk & SKLT & $\sqrt{ }$ & $\sqrt{ }$ & $\sqrt{ }$ & $\sqrt{ }$ \\
\hline 16. & Siantar Top Tbk & STTP & $\sqrt{ }$ & $\sqrt{ }$ & $\sqrt{ }$ & $\sqrt{ }$ \\
\hline 17 & $\begin{array}{l}\text { Ultra Jaya Milk Industry } \\
\text { \& Trading Company } \\
\text { Tbk }\end{array}$ & ULTJ & $\sqrt{ }$ & $\sqrt{ }$ & $\sqrt{ }$ & $\sqrt{ }$ \\
\hline
\end{tabular}

Teknik pengumpulan data dapat dilakukan dengan dokumentasi dan laporan keuangan serta pendukung lainnya. Dalam penelitian ini menggunakan data sebagai berikut.

1. Dokumentasi, proses dokumentasi merupakan sebuah kegiatan yang menjelaskan tentang proses 
pengumpulan data ataupun sebuah informasi yang akan dijadikan bukti kuat pada penelitian

2. Laporan yang akan dilakukan penelitian nanti adalah bagaimana membuat laporandengan ril yaitu untung rugi dan laporan dari neraca yang tercatat di BEI.

\section{Hasil dan Pembahasan}

Hasil satistik deskriptif olahan SPSS untuk data penelitian ini dapat dilihat pada tabel berikut:

Tabel 3. Statistik Deskriptif

\begin{tabular}{|c|c|c|c|c|c|}
\hline & $\mathrm{N}$ & $\begin{array}{r}\text { Minim } \\
\text { um }\end{array}$ & $\begin{array}{r}\mathrm{Ma} \\
\text { xim } \\
\text { um }\end{array}$ & $\begin{array}{r}\mathrm{M} \\
\mathrm{e} \\
\mathrm{a} \\
\mathrm{n}\end{array}$ & $\begin{array}{r}\text { Std. } \\
\text { Deviati } \\
\text { on }\end{array}$ \\
\hline Rasio Aktivitas & 35 & 2.00 & $\begin{array}{r}12.4 \\
6\end{array}$ & $\begin{array}{r}7.35 \\
60\end{array}$ & 2.93996 \\
\hline $\begin{array}{l}\text { Rasio } \\
\text { Produktivitas }\end{array}$ & 35 & .15 & 1.98 & $\begin{array}{r}1.01 \\
71\end{array}$ & .46684 \\
\hline $\begin{array}{l}\text { Rasio } \\
\text { Profitabilitas }\end{array}$ & 35 & -.03 & .21 & $\begin{array}{r}.105 \\
1\end{array}$ & .06993 \\
\hline $\begin{array}{l}\text { Rasio } \\
\text { Likuiditas }\end{array}$ & 35 & .71 & 4.84 & $\begin{array}{r}2.06 \\
80\end{array}$ & 1.15134 \\
\hline $\begin{array}{l}\text { Valid } \\
\text { (listwise) }\end{array}$ & 35 & & & & \\
\hline
\end{tabular}

Sumber: data olah spss Berdasarkan jadual 3 dapat dilihat bahawa dari total minuman, dimana data laporan keuangan yang data 35, nilai nisbah kecairan minimum 0.71 diperoleh, berbentuk pertahun selama kurun waktu lima tahun nilai maksimum 4.84, min 2.0680 dan sisihan piawai periode tahun 2015 sampai dengan 2019. Peneliti dapat 1.15134. Nisbah aktiviti memperoleh nilai minimum mengambil kesimpulan sebagai berikut:

2.00, nilai maksimum 12.46, purata $(\min ) 7.3560$ dan 1. Terdapat pengaruh negatif antara rasio aktivitas sisihan piawai 2.93996. Nisbah produktiviti mempunyai nilai minimum 0.15 , nilai maksimum 1.98 , rata-rata $(\mathrm{min}) 1.0171$ dan mempunyai nilai sisihan piawai 0.46684 . Dan akhirnya nilai nisbah keuntungan memperoleh nilai minimum -0.03 , nilai maksimum 0.21 , rata-rata (min) 0.1051 dan mempunyai sisihan piawai 0.06993. Pada variabel rasio produktivitas diperoleh t-hitung $-2,131<-2.03951$ dan tingkat signifikansinya $0,041<0,05$. Maka dapat disimpulkan bahawa $\mathrm{H} 1$ diterima yang bermaksud terdapat kesan negatif yang signifikan antara nisbah aktiviti dengan kecairan. Ini menunjukkan bahawa nisbah aktiviti yang diukur dengan jumlah perolehan aset mempunyai kesan negatif terhadap kecairan. Yang berarti bahwa, semakin banyak sedikit perputaran total asset akan menyebabkan semakin kecil kemungkinan perusahaan dalam membayar utang jangka pendeknya. Pada variabel rasio produktivitas memperoleh nilai t-hitung sebesar $-0,508>-2.03951$ sedangkan tingkat signifikansinya yaitu $0,615>0,05$. Sehingga hipotesis $\mathrm{H}_{2}$ ditolak yang berarti bahwa tidak terdapat pengaruh antara rasio produktivitas terhadap likuiditas. Hal ini menandakan bahwa sedikit atau banyaknya hasil output perusahaan tidak sertamerta dapat menjamin perusahaan dapat membayar utang jangka pendeknya karena pendapatan perusahaan tidak dapat dilihat dari jumlah output perusahaan, tetapi pendapatan akan dapat dilihat dari hasil penjualan output perusahaan yang dapat menghasilkan kas perusahaan. Variabel rasio profitabilitas Variabel rasio profitabilitas diperoleh nilai t-hitung sebesar $7.933>2.03951$ dan nilai signifikansi sebesar $0.000<0.05$, sehingga hipotesis $\mathrm{H}_{3}$ diterima yang berarti bahwa terdapat pengaruh positif dan signifikan rasio profitabilitas terhadap rasio likuiditas. Hal ini menandakan bahwa meningkatnya penjualan akan membuat profitabilitas perusahaan akan meningkat[11]. Berdasarkan hasil analisis data diperoleh nilai f-hitung 24,014>2.90 dan nilai signifikansi $0.000<0,05$. Hal tersebut menunjukkan bahwa rasio aktivitas, produktivitas dan profitabilitas secara simultan berpengaruh signifikan terhadap rasio likuiditas. Yang berarti, dengan meningkatnya perputaran total asset di ikuti dengan penjualan output yang meningkat sehingga perusahaan akan mendapatkan profit yang meningkat pula. Dengan demikian perusahaan akan dengan mudah dan tepat waktu dalam membayar utang jangka pendeknya atau rasio likuiditas yang pada penelitian ini di ukur dengan Current rasio.

\section{Kesimpulan}

Berdasarkan hasil pengolahan dan analisis data yang telah dilakukan pada perusahaan subsektor makanan dan terhadap likuiditas pada perusahaan makanan dan minuman yang terdaftar di BEI dari tahun 2015 sampai dengan tahun 2019.

2. Tidak ada pengaruh antara nisbah produktiviti terhadap kecairan dalam syarikat makanan dan minuman yang tersenarai di Bursa Saham dari tahun 2015 hingga 2019.

3. Terdapat pengaruh positif dan signifikan antara rasio profitabilitas terhadap likuiditas pada perusahaan makanan dan minuman yang terdaftar di BEI dari tahun 2015 sampai dengan tahun 2019.

4. 4. Nisbah aktiviti serentak, nisbah produktiviti dan nisbah keuntungan mempunyai pengaruh yang signifikan terhadap kecairan dalam syarikat makanan dan minuman untuk tempoh 2015-2019.

5. 5. Nilai $R$ persegi $\left(R^{2}\right)$ yang diselaraskan sebanyak 0.670. Nilai ini menunjukkan kemampuan pemboleh ubah nisbah aktiviti, produktiviti dan keuntungan dalam mempengaruhi pemboleh ubah kecairan adalah 67\%. Dan selebihnya 33\% dipengaruhi oleh pemboleh ubah lain di luar kajian ini. 


\section{Daftar Rujukan}

[1] H. A. Yulitiawati, Desy Mandela, "Pengaruh Rasio Likuiditas, Aktivitas , Profitabilitas dan Leverage Terhadap Return Saham Pada Perusahaan Manufaktur Yang Terdapat Di Bursa Efek Indonesia ( Studi Kasus pada Perusahaan Tekstil dan Garment Tahun 2011-2014 )," vol. 7, no. 2, pp. 228-242, 2019.

[2] T. Afkar, "Pengaruh Profitabilitas Terhadap Likuiditas Bank Umum Syariah di Indonesia," Semin. Nas. Has. Penelit. Univ. Kanjuruhan Malang 2017, vol. 1, no. 1, pp. 629-638, 2017.

[3] M. Barus, N. Sudjana, and S. Sulasmiyati, "PENGGUNAAN RASIO KEUANGAN UNTUK MENGUKUR KINERJA KEUANGAN PERUSAHAAN (Studi pada PT. Astra Otoparts, Tbk dan PT. Goodyer Indonesia, Tbk yang Go Public di Bursa Efek Indonesia)," J. Adm. Bisnis S1 Univ. Brawijaya, vol. 44, no. 1, pp. 154-163, 2017.

[4] 2016). (M.Hanafi \& Halim, "Rasio profitabilitas Nisbah keuntungan menegetahui kekuatan syarikat untuk menjana untung pada tahap jualan, harta dan modal saham tertentu," $J$. AKUTANSI DAN Keuang., vol. 7, no. 2, p. 81, 2016.

[5] Sugiyono, Metode Penelitian Kuantitatif Kualitatif dan $R \& D$, Cetakan Ke. Bandung: Alfabeta, 2014.

[6] d. erica, "analisa rasio laporan keuangan untuk menilai kinerja perusahaan pt kino indonesia tbk," ecodemica, vol. 2, no. 1, pp. 117-124, 2018.

[7] a. hilal and s. samon0, "analysis of the effect of company micro fundamental factors on company value in companies listed in lq 45 index," int. j. econ. financ. issues, vol. 9, no. 4, pp. 115-118, 2019.

[8] v. carolina, e. i. marpaung, and d. pratama, "analisis rasio keuangan untuk memprediksi kondisi financial distress (studi empiris pada perusahaan manufaktur yang terdaftar di bursa efek indonesia periode 2014-2015)," j. akunt. maranatha, vol. 9, no. 2, pp. 137-145, 2018.

[9] s. mudawamah, t. wijono, and r. r. hidayat, "analisis rasio keuangan untuk menilai kinerja keuangan perusahaan (studi pada bank usaha milik negara yang terdaftar di bursa efek indonesia tahun 2013-2015)," j. akunt. bisnis, vol. 54, no. 1, pp. 20-29, 2018.

[10] g. t. akinleye and a. olufemi dadepo, "assets utilization and performance of manufacturing firms in nigeria," int. j. bus. manag., vol. 14, no. 4, p. 107, 2019.

[11] e. w. s. n. kartika hendra titisari, "pengaruh rasiolikuiditas, rasio produktivitas, rasio profitabilitas, dan rasio solvabilitas terhadap peringkat sukuk," j. akunt. dan pajak, vol. 18, no. 01, pp. 130-139, 2017.

[12] r. dadue, i. saerang, and v. untu, "analisis kinerja keuangan industri semen yang terdaftar di bursa efek indonesia," j. ris. ekon. manajemen, bisnis dan akunt., vol. 5, no. 2, 2017.

[13] s. wangdra, "analisis current ratio, debt to total asset ratio,debt to equity ratio, dan net profit margin terhadap harga saham pada perusahaan food and beverage yang terdaftar di bursa efek indonesia," j. akunt. barelang, vol. 3, no. 2, p. 75, 2019.

[14] y. t. janaloka, "analisis rasio keuangan untuk menilai kinerja perusahaan telekomunikasi yang terdaftar di bursa efek indonesia," j. chem. inf. model., vol. 53, no. 9, pp. 1689-1699, 2019.

[15] d. 1. s. intan eprilia, "pengaruh rasio likuiditas dan rasio aktivitas terhadap kinerja keuangan perusahaan manufaktur di bursa efek indonesia," aksara public, vol. 21 , no. 1, pp. 1-9, 2020.

[16] g. ok. w. derfina nofitri anita, agus wahyudi salasa gama, "analisis pengaruh corporate governance terhadap kinerja keuangan sektor perbankan yang terdaftar di bursa efek indonesia ( studi pada perusahaan perbankan yang terdaftar di bursa efek indonesia tahun 2017)," manajemen, vol. 7, no. 1, pp. 45-56, 2017.
[17] dirvi sruya abbas, "pengaruh current ratio, account receivable turnover, inventory turnover, total asset turnover dan debt to equity terhadap return on asset (pada perusahaan sub sektor otomotif dan komponen yang terdaftar di bursa efek indonesia periode 2011-2014)," no. hal 140, 2014. 